DOI https://doi.org/10.30525/978-9934-588-91-4-24

\title{
РУСЬКА (УКРАЇНСЬКА) СКЛАДОВА У ВІЙСЬКУ ВЕЛИКОГО КНЯЗІВСТВА ЛИТОВСЬКОГО
}

\author{
Токар Н. М. \\ кандидат історичних наук, \\ доцент кафедри історії України \\ Центральноукраїнського державного педагогічного університету \\ імені Володимира Винниченка \\ м. Кропивницький, Украӥна
}

Період перебування українських земель під владою Великого князівства Литовського $\epsilon$ вельми суперечливим і малодослідженим. О. Русина стверджує, що три століття (кінець XIII - XVI ст.) нерідко звуть «темними віками» вітчизняної історії через політичну інертність русько-української спільноти порівняно 3 бурхливими подіями кінця XVI-XVII ст. [1, с. 6]. Незважаючи на брак джерел, варто виділити ряд фундаментальних праць українських істориків, які висвітлюють різні сфери життя Литовсько-Руської держави (М. Довнар-Запольський, М. Любавський, Ф. Шабульдо, М. Котляр, В. Смолій, Н. Яковенко, О. Русина) [2]. Окреме місце серед наукових робіт з цієї тематики відведене дослідженню військової справи ВКЛ (М. Грушевський, I. Крип'якевич, Б. Черкас, О. Мальченко, Д. Журавльов) [3]. Однак узагальнюючого грунтовного дослідження, яке б всебічно висвітлило участь населення українських земель у війську ВКЛ, наразі не існує.

Основною військовою силою Великого Князівства Литовського було ополчення військового стану або «земська служба». За вимогою великого князя аристократія Литви й Русі була зобов'язана виставити збройні загони, кількість вояків у яких визначалася розміром земельних володінь удільних князів і бояр.

У XIII - XVI ст. війська удільних князів складалися з дружини та «списів» - дружин васалів. «Спис» (початково «копье», «копие», «kоріе» - польськ.) вперше згаданий літописом під 1153 р., згадується ще в XVI ст. (під 1500 р. вже як «списсы») [4]. Полк, що складався 3 900 «списів», налічував трохи більше 7000 бійців [5]. Після входження окремих князівств до складу ВКЛ їхнє роздроблення призвело до скорочення ресурсів. Наприкінці XIV ст. - на початку XV ст. частина князів могла виставити за наказом великого князя не більше «списа». Так, у війнах Вітовта Кейстутовича та Свидригайла Ольгердовича брали участь десятки князів при невеликій чисельності війська. Особливо це стосується волинських князів, які зберегли свої малі уділи і в XVI ст. Навіть втративши статус удільних володарів, найсильніші з волинських 
князів - Острозькі, Вишневецькі, Чорторийські, Корецькі, Сангушки та Ружинські у XVI - XVII ст. утримували власні війська, які складалися 3 професійних дружин та ополчення васалів [6].

Руські воїни посідали важливе місце у литовському війську. Так, за твердженням О. Уривалкіна, головним сподвижником Гедеміна був руський воєвода Давид, якому була доручена охорона фортеці Гродно i навіть командування армією в тих походах, в яких сам великий литовський князь не брав участі [7, с. 211-212].

Війська руських князів брали участь у всіх визначних битвах Литовської доби. Так, у битві на Синіх Водах (1362р.) до складу загонів вірського війська князів Коріатовичів входили загони васалів 3 Північної Київщини, Чернігівщини і частини Волині [8, с. 67]. У битві на p. Ворсклі (1399 р.) поряд з Гедеміновичами брали участь і руські князі Рюриковичі - Іоанн Борисович київській, Дмитро Данилович Острозький та його брат Олександр [9]. Битва під Вількомиром (1435 р.) між претендентами на литовський стіл Зигмунтом Кейстутовичем і Свидригайлом Ольгердовичем також відбулася за участі руських корогв. Проти 5 тис. дружинників і 4,5 тис. польських лицарів Зігмунта Свидригайло виставив 3 тис. хрестоносців, 1,5 тис. чеської піхоти, близько 500 татар та 2 тис. дружинників українських та білоруських князів, серед яких виділялися Данило і Михайло Гольшанські, Іван Бєльський, Ярослав Семенович (князь мстиславський) [8, с. 76]. Перемогу у битві під Грюнвальдом (1410р.) також було здобуто за участі українськобілоруського війська. В польській армії з 50 корогв 7 нараховувалося 3 українських земель (Галицька, Холмська, Львівська, Перемишльська, Жидачівська, Теребовлянська і Подільська), а з 40 корогв литовської армії 36 були білоруськими або українськими. За приблизними підрахунками, 345 тис. польсько-литовського війська білоруси становили 11 тис., українці - 10 тис., росіяни-новгородці - 500 чоловік, поляки 19 тис., литовці - 3 тис., чехи, морави і сілезці - 1,5 тис.

Першій третина XVI ст. ознаменувалася низкою переможних для литовської держави битв над татарами - під Лопушним (Вишневцем) (1512 р.), під Сокалем (1519 р.) та під Ольшаницею (1527 р.). На чолі руських загонів, які брали у них участь стояли князі Михайло Вишневецький, Андрій Збаразький - у 1512 р.; Василь, Лев і Олександр Корецькі - у 1519 р.; Юрій Слуцький, Федір Сангушко, Олександр Чорторийський, Іван і Олександр Вишневецькі - у 1527 р. Показовим $є$ те, що у всіх трьох вищезгаданих битвах литовсько-руське військо очолював князь Костянин Іванович Острозький, який згодом обіймав посаду великого гетьмана литовського. У знаменитій битві під Оршею (1515 р.) К. Острозький, маючи 30 тис. війська, скористався з взаємних заздрощів двох московських воєвод князя М. Голіцина-Булгакова та I. Челядніна, i розгромив 80 тис. російського війська. За литовськими даними, у полон потрапило 8 воєвод, 37 командирів загонів і 
1500 дворян, загинуло до 30 тис. чоловік. Князь Острозький навмисне імітував відступ, завівши противника під залп своєї артилерії. Ця битва вразила сучасників.

Отже, частка руського елементу у війську Великого князівства Литовського, а згодом і спільної польсько-литовської держави була досить вагомою. Жодна битва цієї держави не обходилася без участі українсько-білоруських полків. На жаль, ми не можемо визначити точне кількісне співвідношення руських і литовських вояків у згаданих баталіях через брак відповідних джерел, але наведені імена руських князів-учасників дають підстави стверджувати, що їхня частка становила не менше половини від загальної чисельності. Таке припущення зумовлене практикою «земської служби», тобто виставленням князями війська в залежності від земельних володінь. А оскільки всі вищеназвані руські князі були великими землевласниками, то цілком вірогідно, що саме їхні надвірні приватні загони становили головну військову силу Литовсько-Руської держави.

\section{Література:}

1. Русина О.В. Україна під татарами і Литвою. К., Видавничий дім «Альтернативи», 1998. 320 с.

2. Довнар-Запольський М.В. Литовські упоминки татарським ордам. Скарбового книга Литовської метрики 1502-1509. Сімферополь, 1898. 91с.; Любавский М. К. Очерки истории Литовско-Русского государства до Люблинской унии включительно. Москва, 1910. 212 с.; Шабульдо Ф. Земли Юго-Западной Руси в составе Великого княжества Литовского. К. 1987; Котляр М. Грошовий обіг на території України доби феодалізму. К., 1971; Смолій В. А.Україна і Литва в XIV-XVI століттях. Політикоправові та соціально-економічні аспекти / Відп. ред; авт. кол.: Берковський В. Г., Блануца А. В., Ващук Д. П., Гурбик А. О., Черкас Б. В. Луцьк: ПрАТ «Волинська обласна друкарня», 2011. 256 с.; Яковенко Н. Українська шляхта 3 кін. XIV до сер. XVII ст. Волинь і Центральна Україна / Н. Яковенко. - Вид. 2-ге, перегл. і випр. К., 2008. 472 с.

3. Грушевський М. Питання оборони замків Великого князівства Литовського в XVI в.. Істор.-геогр. зб. 1928. Т. 2. С. 1-9; Історія українського війська. У 3-х т. / І.Крипякевич, Б.Гнатевич, 3.Стефаеів та ін. Уклад. Б.Якимович. Вид. 5-те, змін. і допов. К.: Варта, 1994; Черкас Б. Степовий щит Литви. Українське військо Гедиміновичів XIV-XVI ст. К.: Темпора, 2011; Мальченко О. Арсенали українських замків XV середини XVII ст. К.: Ін-т української археографії та джерелознавства імені М.С.Грушевського, 2001. 378 с.; Журавльов Д. Визначні битви та полководці української історії. Харків: Книжковий клуб «Клуб Сімейного Дозвілля», 2013. 416 с.

4. Кирпичников А. Н. К оценкам воєнного дела срєдневековой Руси. Древние славяне и Киевская Русь. Киев, 1989. С. 145. 
5. Соловьев С. М. Сочинения. Москва, 1988. Кн. 2, т. 3. -345 с.

6. Спечіунас Вітовт. Стасіс Кнежис. Арвідас Гайдіс Збройні сили Великого князівства Литовського. Стаття Універсальна литовська енциклопедія 31.03.2016 Вільнюс. Електронний ресурс. Режим доступу: https://www.vle.lt/Straipsnis/Lietuvos-Didziosios-Kunigaikstystes-kariuomene-117512

7. Уривалкін О.М. Таємничі грані історії. К.: КНТ, 2007. 340 с.

8. Журавльов Д. Визначні битви та полководці української історії. Харків: Книжковий клуб «Клуб Сімейного Дозвілля», 2013. 416 с.

9. Супрасльській літопис Електронний ресурс. Режим доступу: http://litopys.org.ua/psrl3235/lytov16.htm

DOI https://doi.org/10.30525/978-9934-588-91-4-25

\title{
МАЛА ДУХОВНА СЕМІНАРІЯ У ЛЬВОВІ ЯК СКЛАДОВА БОГОСЛОВСЬКОЇ ОСВІТИ ГКЦ ВПРОДОВЖ 1920-1930-Х РР.
}

\author{
Хоркава I. I. \\ аспіранка кафедри культурології та філософії \\ Національного університету «Острозька академія» \\ м. Острог, Рівненська область, Украӥна
}

Важливим елементом організаційної структури Галицької митрополії Греко-католицької церкви (далі - ГКЦ) були духовні навчальні заклади. Вони сприяли окрім підготовки молодого покоління кліриків, ще й вихованню української молоді на засадах християнського вчення. Серед таких навчальних закладів були духовні семінарії у Львові, Станіславові та Перемишлі. Однак значимою серед них залишалася Львівська духовна семінарія, діяльність якої розпочалася ще 1783 р. Саме в її структурі діяло дві філії, так звані Малі духовні семінарії у Львові та Рогатині [1, с. 142-144]. Отже, метою даної розвідки є аналіз організаційної структури Малої духовної семінарії у Львові впродовж 1920-1930-х pp.

Мала духовна семінарія у Львові була організована ухвалою Львівського Синоду ГКЦ, який розпочав свою роботу 24 вересня 1891 p. Рішенням його учасників духовні семінарії розділялися на два типи, а саме малі та великі. У малих юнаки повинні здобувати середню освіту з обов'язковим прослуховуванням духовних вправ. Якщо за час навчання вони виявили у собі покликання до священичого стану, то після його завершення могли вступати до вищої духовної семінарії; i великі, в яких уже навчалися кандидати духовного стану [2, с. 150]. 